\title{
Terrorism, Religious and Ethnic Intolerance Issues in the Syllabuses and Textbooks of Bengali and English Medium and Madrasha Education in Bangladesh
}

An Appraisal

N.M. Sajjadul HOQUE

\begin{abstract}
Bangladesh, a seventh largest populous and fourth largest Muslim country in the World, is often facing the problems of terrorism, religious and ethnic intolerance. There are many cases of terrorist activities, religious and ethnic intolerance in the recent past. Like many of the post-colonial societies, various national policies were adopted towards facing the challenges of terrorism, religious and ethnic intolerance in Bangladesh. One of the most important policies was formulating National Education Policy (NEP)-2010 though there are a large number of contradictions about the implementation of the NEP. Needless to say peoples of Bangladesh are the victims of terrorism, religious and ethnic intolerance. The Author's perception is education itself a catalyst for social change and it is a powerful instrument in the process of overcoming the problems. In other words, author of this paper believe that syllabuses and text books of both general and madrasha education streams of Bangladesh have significant role in educating people to counter terrorism, religious and ethnic intolerance. However, an attempt has been made in this paper through reviewing the current syllabuses and text books of general and madrasha education streams and also through assessing the peoples' opinions of Bangladesh to know whether the syllabuses and text books are adequately addressing the issues of terrorism, religious and ethnic intolerance or not.
\end{abstract}

Keywords: countering terrorism, religious and ethnic intolerance; syllabuses and textbooks

\section{Introduction}

Bangladesh has been experiencing a number of growing threats that shake the roots of country. Most notable three are Terrorism, Ethnic intolerance, and Religious intolerance. However, Bangladesh has experienced dramatic stabilization of these issues for some years especially in terrorism; 
nevertheless, all of these issues have not been eliminated. Even to some extents, some issues are growing more rapidly. Different reports and researches demonstrate the recent trends of these threats. One of the most concerned issues of these threats from different investigations in several times is an external linkage between the extremist of Bangladesh with the outer world. The linkage posits Bangladesh against the world that is fighting against terrorism. This is creating at the same time a ground for international community to intervene with the internal matter of country in the name of combating terrorism. Therefore, one of the most important tasks of the country is to stabilize its internal condition, delink the terrorist connections with the outer world, and make dysfunctional terrorist ingredients. This is very significant but a difficult one. To perform this difficult task, mass awareness is essential. Education could be the best tool for creating awareness. Therefore, we need academic curricula, syllabuses and text books that would effectively address the concern issues. By keeping this in mind, present study, with the following objectives, has been conducted to understand the present scenario of syllabuses and text books of Bangladesh, whether the issues like terrorism, religious and ethnic intolerance are addressed in the syllabuses and text books or not.

Objectives

- To find out the availability of the issues such as counter terrorism, religious and ethnic intolerance in the syllabuses and text books of Bangladesh.

- To seek the opinions and observations of different personalities relevant to educational sectors/systems on several issues such as counter terrorism, religious and ethnic intolerance.

\section{Methodology}

This study was conducted on the basis of both qualitative and quantitative methodology. Both primary and secondary data have been and analyzed in this study.

Syllabuses [approved by Ministry of Education (MoE)] of Class I to Class XII education level, viz, primary and Ebtadayee (Primary level of Madrasha education), Junior Secondary and Secondary level that is Dakhil in Madrasha education, and Higher Secondary that is Alim in Madrasha education were reviewed.

The textbooks approved by National Curriculum Textbook Board (NCTB), Bangladesh Madrasha Education Board, and English Medium curriculum 
were also reviewed along with the following textbooks:

- Social Studies of Class III, V, VII, VIII, Secondary and Higher Secondary Level;

- Religious studies of class V, VIII, and Secondary level.

Class III was selected as the beginning level of Social science and Religious Studies, and Class V as the end of Primary level education in this study. Similarly Class VIII was selected as the end of Lower Secondary, Class IX as Secondary and Class XI and XII from the Higher Secondary Studies. 9 (Nine) books of different levels of education in Bangladesh has been analyzed to conduct this study. Though both general and madrasha education streams are different but their books are to some extents compatible each other. For instance, social sciences books in both madrasha and general education are same. General science, mathematics and english are also same. These books were also reviewed.

Moreover, a common questionnaire was prepared and used to collect data for this study. Previously it was decided to collect data from all categories in a proportionate way but due to shortage of respondents it was not possible. The questionnaire included questions for all participants, specific for teachers, students, guardians, journalists, politicians and persons related to education system of Bangladesh in four major divisions of Bangladesh; Dhaka, Chittagong, Rajshahi \& Sylhet. Open and close ended both types of questions were there.

Translation: The questionnaire was developed in English then translated in Bengali so that it can be understandable to general Bangladeshi respondents.

Population: The survey was done on 500 respondents from four major divisions of different age, religion, gender, educational qualification and ethnicity.

Field work period: June-July, 2012

Sampling Methodology: The sample of this study was a stratified probability sampling with 125 randomly selected respondents from different school, colleges, universities, madrashas' and from others covering four divisions-Dhaka, Rajshahi, Sylhet and Chittagong. It was tried to collect sample in a proportional manner but due to lack of respondents from desired stratification it couldn't be done. Out of 500, 463 respondents (students and teachers from primary to university levels) were from educational institutions including religious educational institutions (411 respondents were from different educational institutions 
and 52 were from madrasha) and 37 respondents were from the pool of politician, journalist, guardian and person relating to education policy.

In-depth interview of 10 persons relevant to the research was done for this study.

\section{Data Processing and Analysis}

After completing the field investigation, all the questionnaires were edited and some errors were detected and corrected accordingly. Data were coded and entered onto computers, with analysis completed by using Statistical Package for Social Sciences (SPSS). In-depth interviews results were used to elaborate and clarify findings.

\subsection{Glimpse of Terrorism, Ethnic and Religious intolerance in Bangladesh}

Bangladesh has been experiencing a number of growing threats like terrorism, ethnic and religious intolerance. To understand the situation of terrorism, ethnic, and religious intolerance in Bangladesh, we need to decipher the present condition of these issues.

\section{a. Terrorism}

Terrorism became a serious concern issue for Bangladesh especially after happening some incredible incidents like Jamiatul Mujahedin Bangladesh (JMB)'s rise, Udichi's Attack, and their series bomb attack all over the country in a same time, for the policy makers who have failed initially to restrain them and for the general people who are constantly feel threat of terrorism. There are over 50 such Islamist militant-extremist groups in Bangladesh (Barakat, 2011a). ${ }^{1}$ Moreover, there are 10 (ten) religious based political parties in Bangladesh. These are Bangladesh Jamaete-Islami, Zaker Party, Bangladesh Tarikat Federation, Bangaldesh Khelaphat Andolon, Bangladesh Muslim League, Jamiat e Ulama e Islam Bangladesh, Islamic Front Bangladesh, Islami Oikko Jot, Khelafat Majlish, Islami Andolon Bangladesh (Election Commission of Bangladesh, 2012). Many of them have student wings like Islami Chatra Sibir of Jamaet e Islam. There are non-religious terrorists parties exists in the country, like as Gono Bahini, Alom-Swapan Bahini, Purba Bangla Communist PartyJanajuddha, Purba Bangla Communist Party -Lal Pataka,Gono Mukti Fouz. South Asia Terrorism Portal (SATP) gives a data on 'Fatalities -Islamist Terrorism, 2005-2012' in where it indicates the casualties of terrorism in Bangladesh. SATP also published a list of terrorist violence since 1996. This organization published terrorist activities from 1996 to 
Table: 1: Fatalities-Islamist Terrorism 2005 - 2012

\begin{tabular}{|c|c|c|c|c|}
\hline Year & Civilian & SFs & Terrorists & Total \\
\hline 2005 & 26 & 0 & 9 & 35 \\
\hline 2006 & 6 & 0 & 6 & 12 \\
\hline 2007 & 1 & 0 & 7 & 8 \\
\hline 2008 & 1 & 0 & 0 & 1 \\
\hline 2009 & 0 & 0 & 0 & 0 \\
\hline 2010 & 3 & 0 & 3 & 6 \\
\hline 2011 & 0 & 0 & 0 & 0 \\
\hline 2012 & 1 & 0 & 2 & 3 \\
\hline Total & 38 & 0 & 27 & 65 \\
\hline
\end{tabular}

(SATP, 2012)

There were 25 major terrorist attacks happened in the Bangladesh since 1999. Most of them happened by the extremist parties. The attacks were mainly on religious consideration and on minority groups, secular writers. (Table: 2)

Table 2: Attacks by Terrorist groups

\begin{tabular}{|l|l|l|}
\hline \multicolumn{1}{|c|}{$\begin{array}{c}\text { Date of } \\
\text { occurrence }\end{array}$} & \multicolumn{1}{|c|}{ Target act: nature and place } & \multicolumn{1}{c|}{ Visible loss } \\
\hline 6 March 1999 & $\begin{array}{l}\text { Bomb explosion at cultural } \\
\text { program of Udichi, Jessore }\end{array}$ & 10 killed, 105 injured \\
\hline 8 October 1999 & $\begin{array}{l}\text { Bomb explosion on Ahmedia } \\
\text { Mosque, Khulna }\end{array}$ & 8 killed, 32 injured \\
\hline 20 January 2001 & $\begin{array}{l}\text { Time bomb explosion in CPB } \\
\text { meeting, Dhaka }\end{array}$ & 7 killed, 52 injured \\
\hline 14 April 2001 & $\begin{array}{l}\text { Bomb explosion on Pahela } \\
\text { Baisakh (Bengali new year) } \\
\text { celebration, Dhaka }\end{array}$ & 11 killed, 120 injured \\
\hline 3 June 2001 & $\begin{array}{l}\text { Time bomb explosion in Church, } \\
\text { Gopalgonj }\end{array}$ & 10 killed, 25 injured \\
\hline 16 June 2001 & $\begin{array}{l}\text { Bomb explosion on Awami } \\
\text { League Office, Narayangonj }\end{array}$ & 22 killed, 50 injured \\
\hline $\begin{array}{l}\text { 16 November } \\
\text { 2001 }\end{array}$ & $\begin{array}{l}\text { Killing of Hindu educationist, } \\
\text { Principal Gopal Krishna Muhuri }\end{array}$ & Killed \\
\hline
\end{tabular}




\begin{tabular}{|c|c|c|}
\hline 21 April 2002 & $\begin{array}{l}\text { Killing of Buddhist monk, } \\
\text { Gainjoti Mohathero }\end{array}$ & Killed \\
\hline $\begin{array}{l}7 \text { December } \\
2002\end{array}$ & $\begin{array}{l}\text { Bombing in } 4 \text { cinema halls, } \\
\text { Mymensingh }\end{array}$ & 27 killed, 298 injured \\
\hline 17 January 2003 & $\begin{array}{l}\text { Bombing in Sufi Shrine, } \\
\text { Sakhipur, Tangil }\end{array}$ & 7 killed, 26 injured \\
\hline 12 January 2004 & $\begin{array}{l}\text { Bombing in Shahjalal Sufi } \\
\text { Shrine, Sylhet }\end{array}$ & 5 killed, 52 injured \\
\hline 27 February & $\begin{array}{l}\text { Deadly attack on secular writer, } \\
\text { Professor Humayun Azad (of } \\
\text { Dhaka University) }\end{array}$ & Died after injury \\
\hline 2 April 2004 & $\begin{array}{l}\text { Deadly cargo, Chittagong: } \\
2000 \text { automatic/semi automatic } \\
\text { weapons, } 40 \text { rocket-propelled } \\
\text { grenades (RPG), } 25,000 \text { hand } \\
\text { grenades, } 1.8 \text { million rounds of } \\
\text { small arms ammunition. }\end{array}$ & - \\
\hline 21 May 2004 & $\begin{array}{l}\text { Bombing in Shahjalal Sufi } \\
\text { Shrine, Sylhet }\end{array}$ & $\begin{array}{l}3 \text { killed, } 65 \text { injured } \\
\text { including British High } \\
\text { Commissioner }\end{array}$ \\
\hline 21 August 2004 & $\begin{array}{l}\text { Grenade attack on leader of } \\
\text { the opposition (Sheikh Hasina) } \\
\text { in a public meeting: Biggest } \\
\text { awakening. }\end{array}$ & 24 killed, 503 injured \\
\hline 27 January 2005 & $\begin{array}{l}\text { Grenade attack in a public } \\
\text { meeting of the opposition }\end{array}$ & $\begin{array}{l}5 \text { killed including } \\
\text { former Finance } \\
\text { Minister S.A.M.S. } \\
\text { Kibria (a member of } \\
\text { Parliament, and former } \\
\text { UN under Secretary } \\
\text { General) }\end{array}$ \\
\hline $\begin{array}{l}17 \text { February } \\
2005\end{array}$ & $\begin{array}{l}\text { Bombing on NGO offices } \\
\text { (BRAC), Raipur, Naogaon }\end{array}$ & - \\
\hline 17 August 2005 & $\begin{array}{l}\text { Great awakening: } 500 \text { serial } \\
\text { bombing across country in } 30 \\
\text { minutes }\end{array}$ & $\begin{array}{l}\text { (A highly coordinated } \\
\text { terrorist activity) }\end{array}$ \\
\hline $2003-2005$ & $\begin{array}{l}\text { Murder by Bangla Bhai group } \\
\text { (JMB), North Bengal }\end{array}$ & 35 killed, 123 injured \\
\hline
\end{tabular}




\begin{tabular}{|l|l|l|}
\hline 3 October 2005 & $\begin{array}{l}\text { Bombing in 3 Court } \\
\text { buildings(Chandpur, Laxmipur, } \\
\text { Chittagong) }\end{array}$ & 2 killed, 39 injured. \\
\hline $\begin{array}{l}\text { 14 November } \\
2005\end{array}$ & $\begin{array}{l}\text { Bombing in Government } \\
\text { residence, Jhalokhathi }\end{array}$ & 2 killed, 4 injured \\
\hline $\begin{array}{l}29 \text { November } \\
2005\end{array}$ & $\begin{array}{l}\text { Bombing in Lawyers Association } \\
\text { Building, Gazipur }\end{array}$ & 10 killed, 220 injured \\
\hline $\begin{array}{l}29 \text { November } \\
2005\end{array}$ & $\begin{array}{l}\text { Bombing in a Police Box, } \\
\text { Chittagong }\end{array}$ & 3 killed, 25 injured \\
\hline $\begin{array}{l}1 \text { December } \\
2005\end{array}$ & $\begin{array}{l}\text { Bombing on Deputy } \\
\text { Commissioner's Office, Gazipur }\end{array}$ & 1 killed, 50 injured \\
\hline $\begin{array}{l}\text { 8 December } \\
2005\end{array}$ & $\begin{array}{l}\text { Bomb explosion on Udichi } \\
\text { Cultural Office, Netrokona }\end{array}$ & 8 killed, 100 injured \\
\hline
\end{tabular}

Source : Barakat, 2011b

After all, the recent trends of terrorism are satisfactory and the country has experiencing a dramatic stabilization over the past years. According to SATP there have been no fatalities related with Islamists in 2011, same as in 2010. The government has moved forward toward tackling these problems. By November 6, 2011, the Government had arrested 576 militants belonging to various Islamist extremist groupings, including the Jamaat-eIslami, Islami Chhatra Shibir, Jama'at-ul-Mujahideen Bangladesh (JMB), Hizb-ut-Tahrir (HuT), and Hizb-ut-Towhid, as against 958 such arrests in 2010, and 23 in 2009. The pattern of arrests over the year suggests that the principal concentration has been directed against HuT and Hizb-utTowhid, because of their active penetration into the Bangladeshi society. 165 cadres belonging to these two outfits have been arrested in 30 incidents throughout 2011, including Mahmudul Bari, adviser of HuT and Rajshahi District Ameer (Chief) of Hizb-ut-Towhid, Mohammad Mizanur Rahman. These two organizations have been involved in the aggressive propagation of extremist Islamist ideologies in the country.

\section{b. Religious Intolerance}

Religious intolerance is one of the major concerning issues when the rate of religious hatred and the minority's rights violation of the country are constantly increasing. The religious minorities of the country are feeling threat for prosecution and domination of majority religious community. The right to life, right to liberty and the right to worship are in the brink. Some recent incidents portray the sketch of religious intolerance.

On September 30, 2012 mobs demolished 12 Buddhists temples and 
monasteries and more than 50 houses in Ramu Upazila at Cox's bazar. Some terrorists also destroyed two monasteries and a Hindu temple in Chittagong and torched two monasteries at Ukhia and five houses at Teknaf upazila in Cox's Bazar.

In the beginning of 2011, the theft of large amounts of gold and money from the Dhakeshwari Temple, considered Bangladesh's "national temple", in the capital city of Dhaka, left the Hindu community deeply shocked and traumatized. Thieves also stole valuables from the Kadamtala Kali Temple in Dhaka. Different report also asserts that 23rd of such temple were looted in last two months. A "Harinam Sankirtan" a Hindu religious festival, was attacked in Sunamganj in March 2011. It was claimed by the Hindu Buddhist Christian Unity Council that the police refused to take action. In April 2011, International Society for Krishna Consciousness (ISKCON) temple was attacked and a copy of the Bhagavad Gita burned in Sylhet district in April. In same month, a group of Muslims attacked a journalist, damaged a temple, and attacked several Hindu families in Ukiara village. Fortunately, police acted quickly and arrested 11 people. A group Muslim carrying weapons attacked a Hindu temple the Narayan Shiva Mandir in Khasa Pandith Para of Beani Bazar in Sylhet District on April 2. The attackers destroyed Laksmi Narayan temple and looted 80,000 Taka. A priest also assaulted. In September, the Dainik Azadi a newspaper reported that a temple dedicated to the Goddess Durga in Bandarban district was attacked and destroyed. On the same day, Bhorer Kagoj, another newspaper, reported that jewelry and a Hindu deity were stolen from a temple in Patia town in Chittagong. In the same month, a deity being prepared for the Durga puja festival was destroyed in Narayanganj, according to the Ittefaq newspaper (Hindu American Foundation, 2012).

\section{c. Ethnic Intolerance}

Ethnic intolerance grew because of historical fault by the majority community to ethic communities with the mainstream communities, in other words, by ignoring small and ethnic communities during state building. The problem of intolerance jeweled with other problems like gross human rights violation of ethnic communities by major communities. A several incidents indicate the intolerance level between major and minor communities. This problem is acute in especially in the Chittagong Hill Tracts (CHT) region as well as the Indigenous people concentrated area in plain land of the country. The history of Human Rights Violation is as long as the independence of Bangladesh and even before. According to Human 
Rights Report 2011 on Indigenous Peoples in Bangladesh, 51 incidents of Human Rights violation happened in 2011 all over the country. (Table: 3)

Table: 3: Gross Human Rights Violation and Casualties of Indigenous

People $^{2}$

\begin{tabular}{|l|c|c|c|}
\hline \multicolumn{1}{|c|}{ Violation } & CHT & Plain & Total \\
\hline Arrest and Detention & 13 & 1 & 14 \\
\hline Killing & 3 & 4 & 7 \\
\hline Torture and Intimation & 29 & 1 & 30 \\
\hline Total & 45 & 6 & 51 \\
\hline
\end{tabular}

Source : Barman and Neo, 2012

Moreover, if we flash back to last 10 years then the scenario would be clearer to us. A report of Parbattya Chattagram Jana Shanghati Shamity (PCJSS) on Human Rights claimed there are 648 violation of rights happened against the indigenous people in 2009 and 2010 where the number of last 10 years, from 1998-2008, were 4755(Tables: 4 and 5).

Table: 4: Human rights of the CHT (2009-2010)

\begin{tabular}{|c|c|c|c|c|c|c|c|c|c|c|c|}
\hline \multirow[t]{2}{*}{$\begin{array}{l}\text { Form of } \\
\text { atrocity }\end{array}$} & \multirow[t]{2}{*}{$\begin{array}{l}\text { Perpe } \\
\text { trator }\end{array}$} & \multicolumn{2}{|c|}{$\begin{array}{l}\text { Security } \\
\text { Forces }\end{array}$} & \multicolumn{2}{|c|}{$\begin{array}{l}\text { Bengali } \\
\text { Settlers }\end{array}$} & \multicolumn{2}{|c|}{$\mathrm{SF}+\mathrm{BS} *$} & \multicolumn{2}{|c|}{ UPDF** } & \multicolumn{2}{|c|}{ Total } \\
\hline & & 2009 & 2010 & 2009 & 2010 & 2009 & 2010 & 2009 & 2010 & 2009 & 2010 \\
\hline $\begin{array}{l}\text { No. of } \\
\text { person } \\
\text { killed }\end{array}$ & 1 & 2 & 2 & 2 & - & 25 & 6 & 2 & 2 & 10 & \\
\hline $\begin{array}{l}\text { No. of } \\
\text { person } \\
\text { tortured }\end{array}$ & 33 & 14 & 14 & 26 & - & & 11 & 5 & 52 & 76 & \\
\hline $\begin{array}{l}\text { No. of } \\
\text { person } \\
\text { arrested }\end{array}$ & 7 & & & & - & & & & 7 & & \\
\hline $\begin{array}{l}\text { No. of } \\
\text { person } \\
\text { harassed }\end{array}$ & 12 & 3 & 1 & 18 & - & & & 25 & 38 & 21 & \\
\hline $\begin{array}{l}\text { No. of } \\
\text { person } \\
\text { against } \\
\text { whom case } \\
\text { lodged }\end{array}$ & & & & & - & & & & & & \\
\hline
\end{tabular}




\begin{tabular}{|c|c|c|c|c|c|c|c|c|c|c|}
\hline $\begin{array}{l}\text { No. of } \\
\text { house set } \\
\text { fire }\end{array}$ & & & 7 & 70 & - & 434 & & & 7 & 504 \\
\hline $\begin{array}{l}\text { No. of } \\
\text { house } \\
\text { looted \& } \\
\text { destructed }\end{array}$ & & 9 & 4 & 5 & - & & & & 4 & 14 \\
\hline $\begin{array}{l}\text { No. of } \\
\text { house } \\
\text { searched }\end{array}$ & & & & & - & & & & & \\
\hline $\begin{array}{l}\text { No. of } \\
\text { woman } \\
\text { raped }\end{array}$ & & & 3 & 2 & - & 1 & & & 3 & 3 \\
\hline $\begin{array}{l}\text { No. of } \\
\text { woman } \\
\text { sexually } \\
\text { harassed }\end{array}$ & 1 & 3 & 2 & 5 & - & & & & 3 & 8 \\
\hline $\begin{array}{l}\text { No. of } \\
\text { person } \\
\text { kidnapped }\end{array}$ & & & 1 & & - & & 9 & 10 & 11 & 9 \\
\hline $\begin{array}{l}\text { No. of } \\
\text { person } \\
\text { whose land } \\
\text { grabbed }\end{array}$ & & & & 3 & - & & & & & 3 \\
\hline Total & 54 & 31 & 34 & 131 & - & 460 & 26 & 42 & 130 & 648 \\
\hline
\end{tabular}

* SF= Security Forces and BS= Bengali Settlers ** UPDF: United People's Democratic Front

(PCJSS, 2012)

Table: 5: Human rights of the CHT (1998-2008)

\begin{tabular}{|l|l|l|l|l|l|}
\hline $\begin{array}{l}\text { Form of } \\
\text { atrocity }\end{array}$ & $\begin{array}{l}\text { Security } \\
\text { Forces }\end{array}$ & $\begin{array}{l}\text { Bengali } \\
\text { Settlers }\end{array}$ & SF+BS* & UPDF** & Total \\
\hline No. of person killed & 26 & 15 & 2 & 84 & 127 \\
\hline No. of person tortured & 709 & 207 & 286 & 131 & 1333 \\
\hline No. of person arrested & 348 & 4 & 6 & & 358 \\
\hline No. of person harassed & 243 & 44 & 1 & 85 & 373 \\
\hline $\begin{array}{l}\text { No. of person against whom } \\
\text { case lodged }\end{array}$ & 106 & 24 & & 74 & 204 \\
\hline No. of house set fire & 15 & 170 & 435 & 55 & 675 \\
\hline $\begin{array}{l}\text { No. of house looted \& } \\
\text { destructed }\end{array}$ & 64 & 378 & 650 & 37 & 1129 \\
\hline No. of house searched & 37 & & & 11 & 48 \\
\hline
\end{tabular}




\begin{tabular}{|l|l|l|l|l|l|}
\hline No. of woman raped & 10 & 32 & 11 & 1 & 54 \\
\hline $\begin{array}{l}\text { No. of woman sexually } \\
\text { harassed }\end{array}$ & 11 & 11 & 1 & & 23 \\
\hline No. of person kidnapped & 3 & 7 & & 307 & 317 \\
\hline $\begin{array}{l}\text { No. of person whose land } \\
\text { grabbed }\end{array}$ & 23 & 72 & 19 & & 114 \\
\hline Total & 1595 & 964 & 1411 & 785 & 4755 \\
\hline
\end{tabular}

$* \mathrm{SF}=$ Security Forces and $\mathrm{BS}=$ Bengali Settlers, ** UPDF: United People's Democratic Front

(PCJSS, 2012)

\subsection{A Review of the Syllabuses and Textbooks of Bengali and English Medium and Madrasha Education}

Education is a useful tool for creating awareness against terrorism, religious and ethnic intolerance. We reviewed the syllabuses and textbooks of two major mainstream education system, viz, Madrasha and General education to see how much the issues of terrorism, religious and ethnic intolerance are covered by the syllabuses and text books.

The following table shows our syllabus scrutinization:

Table: 6 Three Issues in Syllabuses (at a glance)

\begin{tabular}{|c|c|c|c|c|c|c|}
\hline \multirow{3}{*}{$\begin{array}{c}\text { Syllab } \\
\text { uses } \\
\end{array}$} & \multicolumn{6}{|c|}{ Ethnic intolerance, Religious intolerance, Terrorism } \\
\hline & \multicolumn{3}{|c|}{ Social Science (SS) } & \multicolumn{3}{|c|}{ Religious Studies (RS) } \\
\hline & Chapter & Title & Page & Chapter & Title & Page \\
\hline Class I & \multicolumn{6}{|c|}{ Reviewed Books are Not Available } \\
\hline Class II & \multicolumn{6}{|c|}{ Reviewed Books are Not Available } \\
\hline Class III & $\begin{array}{l}\text { Chapter } 2 \\
\text { Chapter } 10\end{array}$ & $\begin{array}{c}\text { We all are man } \\
\text { Title Democratic } \\
\text { opinion }\end{array}$ & $\begin{array}{c}2-8 \\
50-57\end{array}$ & $\mathrm{X}$ & $\mathrm{X}$ & $\mathrm{X}$ \\
\hline Class IV & $\mathrm{X}$ & $\mathrm{X}$ & $\mathrm{X}$ & $\mathrm{X}$ & $\mathrm{X}$ & $\mathrm{X}$ \\
\hline Class V & $\begin{array}{l}\text { Chapter } 6 \\
\text { Chapter } 16\end{array}$ & $\begin{array}{l}\text { Tolerance of others } \\
\text { opinion } \\
\text { Different group of } \\
\text { ethnic indigenous } \\
\text { people of Bangladesh }\end{array}$ & $\begin{array}{c}45-51 \\
166-175\end{array}$ & $\begin{array}{c}\text { Chapter } \\
3\end{array}$ & Integrity & $81-83$ \\
\hline Class VI & $\mathrm{X}$ & $\mathrm{X}$ & $\mathrm{X}$ & $\mathrm{X}$ & $\mathrm{X}$ & $\mathrm{X}$ \\
\hline $\begin{array}{c}\text { Class } \\
\text { VII }\end{array}$ & Chapter 3 & $\begin{array}{l}\text { Giving importance to } \\
\text { other opinion }\end{array}$ & 25 & $\mathrm{X}$ & $\mathrm{X}$ & $\mathrm{X}$ \\
\hline $\begin{array}{l}\text { Class } \\
\text { VIII }\end{array}$ & Chapter 11 & Tribals of Bangladesh & $101-112$ & $\begin{array}{c}\text { Chapter } \\
4\end{array}$ & $\begin{array}{l}\text { National } \\
\text { Unity }\end{array}$ & $66-85$ \\
\hline
\end{tabular}




\begin{tabular}{|c|c|c|c|c|c|c|}
\hline $\begin{array}{l}\text { Class } \\
\text { IX-X }\end{array}$ & $X$ & $X$ & $X$ & $X$ & $X$ & $X$ \\
\hline $\begin{array}{c}\text { Class } \\
\text { XI-XII }\end{array}$ & $\begin{array}{c}\text { Chapter12 } \\
\text { (Paper I) } \\
\text { Chapter } 8 \\
\text { (Paper II) }\end{array}$ & $\begin{array}{c}\text { Religious System } \\
\text { Ethnic communities of } \\
\text { Bangladesh }\end{array}$ & $\begin{array}{l}193-214 \\
101-120\end{array}$ & $X$ & $X$ & $X$ \\
\hline
\end{tabular}

Note: Here, SS means all books related to Social Sciences (that vary in class to class in different level), and RS means Religious Studies.

In our analysis, we did not find any direct lesson regarding counter terrorism, religious and ethnic intolerance in these reviewed syllabuses. Based on syllabus review, we selected textbooks and the following table will enumerate issues found by textbooks review.

Table: 7 Three Issues in Textbooks (at a glance)

\begin{tabular}{|c|c|c|c|c|c|c|}
\hline $\begin{array}{l}\text { Text } \\
\text { Book }\end{array}$ & \multicolumn{2}{|c|}{ Ethnic intolerance } & \multicolumn{2}{|c|}{$\begin{array}{l}\text { Religious } \\
\text { intolerance }\end{array}$} & \multicolumn{2}{|c|}{ Terrorism } \\
\hline & SS & RS & SS & RS & SS & $\overline{R S}$ \\
\hline $\begin{array}{l}\text { Class } \\
\text { III }\end{array}$ & $\begin{array}{l}\text { All men are equal, but } \\
\text { not directly mentioned } \\
\text { ethnic intolerance }\end{array}$ & & $\mathrm{X}$ & & $\mathrm{X}$ & \\
\hline Class V & $\begin{array}{l}\text { In chapter Six, } \\
\text { mentioned about the } \\
\text { tolerance of other } \\
\text { opinion in difference } \\
\text { issues means to respect } \\
\text { others opinion and } \\
\text { independency of other } \\
\text { class, profession, and } \\
\text { religion to express their } \\
\text { opinion (page.45), but } \\
\text { not mentioned ethnic } \\
\text { tolerance. } \\
\text { In the same book in } \\
\text { Chapter Sixteen, there } \\
\text { is an introductory } \\
\text { overview on Indigenous } \\
\text { community and ethnicity } \\
\text { of Bangladesh. Here } \\
\text { it is emphasized in } \\
\text { Conclusion "We should } \\
\text { respect their ways of life } \\
\text { and extend our helping } \\
\text { hands whenever they } \\
\text { need." (page, } 173 \text { ) }\end{array}$ & $\mathrm{X}$ & $\mathrm{X}$ & $\mathrm{X}$ & $\mathrm{X}$ & $\mathrm{X}$ \\
\hline
\end{tabular}




\begin{tabular}{|c|c|c|c|c|c|c|}
\hline $\begin{array}{l}\text { Class } \\
\text { VII }\end{array}$ & $\bar{X}$ & $\mathrm{X}$ & $\begin{array}{l}\text { In chapter } \\
\text { III, it is } \\
\text { mentioned } \\
\text { that the role } \\
\text { of culture } \\
\text { in religious } \\
\text { harmony } \\
\text { (Page 25), } \\
\text { but not } \\
\text { mentioned } \\
\text { Religious } \\
\text { intolerance. }\end{array}$ & $\bar{X}$ & $\mathrm{X}$ & $\mathrm{X}$ \\
\hline $\begin{array}{l}\text { Class } \\
\text { VIII }\end{array}$ & $\begin{array}{l}\text { In chapter } 11 \text {, the } \\
\text { lifestyle of Tribal only } \\
\text { mentioned from 101-112 } \\
\text { page. }\end{array}$ & $\begin{array}{l}\text { In Chapter } 4 \text {, } \\
\text { It is mentioned } \\
\text { that the } \\
\text { tolerance } \\
\text { of other } \\
\text { communities } \\
\text { intolerance. }\end{array}$ & $\mathrm{X}$ & $\mathrm{X}$ & $\bar{X}$ & $\mathrm{X}$ \\
\hline $\begin{array}{l}\text { Class } \\
\text { IX-X }\end{array}$ & $\mathrm{X}$ & $\mathrm{X}$ & $\bar{X}$ & $\bar{X}$ & $\bar{X}$ & \\
\hline $\begin{array}{l}\text { Class } \\
\text { XI-XII }\end{array}$ & $\begin{array}{l}\text { Life style, and only } \\
\text { described that 'they are } \\
\text { deserving equal rights' }\end{array}$ & $\bar{X}$ & $\begin{array}{l}\text { In social } \\
\text { studies, in } \\
\text { p.193-214, } \\
\text { here role } \\
\text { religion as } \\
\text { a unity in } \\
\text { socialization } \\
\text { process }\end{array}$ & $\bar{X}$ & $\bar{X}$ & $\bar{X}$ \\
\hline
\end{tabular}

Note: Here, SS means all books related to Social Sciences (that vary in class to class in different level), and RS means Religious Studies. In our analysis, we did not find any direct lesson regarding counter terrorism, religious and ethnic intolerance in these reviewed books.

In the study, it worryingly noticed that the three of the most vital issues, viz, terrorism, religious intolerance and ethnic intolerance are not covered by the syllabuses and text books, where other issues like dowry, population problem etc. is covered. It is essential to include these issues immediately, as to the students can aware of these issues.

\section{Field Data Analysis and Discussion}

\subsection{Terrorism, religious and ethnic intolerance in bangladesh}

To know that, how people view terrorism, religious and ethnic intolerance 
in Bangladesh, some questions have been asked. It has been asked that whether terrorism, religious and ethnic intolerance are a problem. The respondents' responses are given in the following figure:

\section{$71.60 \%$}

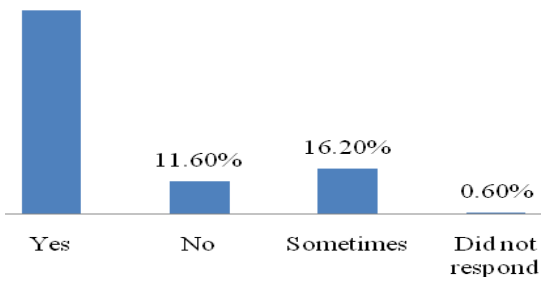

$71.6 \%$ respondents shared that they think terrorism, religious and ethnic intolerance are a problem for Bangladesh. Sometimes these are problem was shared by $16.20 \%$ respondents. These issues are no problem for Bangladesh was shared by $11.60 \%$ respondents.

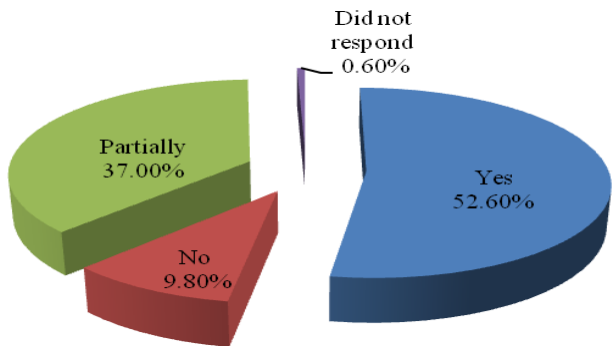

Q.2. Are you concerned about these issues?

$52.60 \%$ respondents shared that they are concerned about the issues of, terrorism, religious and ethnic intolerance, and 37\% respondents shared that they think about the issues partially. 9.80\% respondents shared that they are not concern about the issues of terrorism, religious and ethnic intolerance.

Over all, it was found that, in Bangladesh majority of the respondents think and concern about the issues of terrorism, religious and ethnic intolerance.

\subsection{Terrorism, religious and ethnic intolerance issues in syllabuses and text books}

Through some probing questions, it was tried to gather information on position of terrorism, religious and ethnic intolerance issues in text books and syllabuses. Respondent's answers are given as following: 
$22.31 \%$

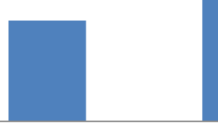

$2.69 \%$

Yes

No

Did Not

respond

Q. 3. Do you have any chapter/topic related to Counter Terrorism, Religious, and Ethnic intolerance in your syllabuses/Textbooks?

The total respondents as student was $372,74.40 \%$ of total respondents and among them $75 \%$ student shared that they do not have any chapter or topic related to counter terrorism, religious and ethnic intolerance. Only $22.31 \%$ shared that they have some contents. The frequency of responding yes was 83. Among 83 respondents, who said yes, only 33 people shared the topic or chapter names.

Among all contents, religion study topics were common. Anthropology of religion, terrorism and politics, Santal rajniti (Santal Politics) are some common answers from the respondents. Secondary level students shared about some topics from their religion book and Bengali literature book. They talked about some story and poetry (titled "Duranta Pathik", "Avijatrik") which found inspirational for shaping their character to counter any inhumanity.

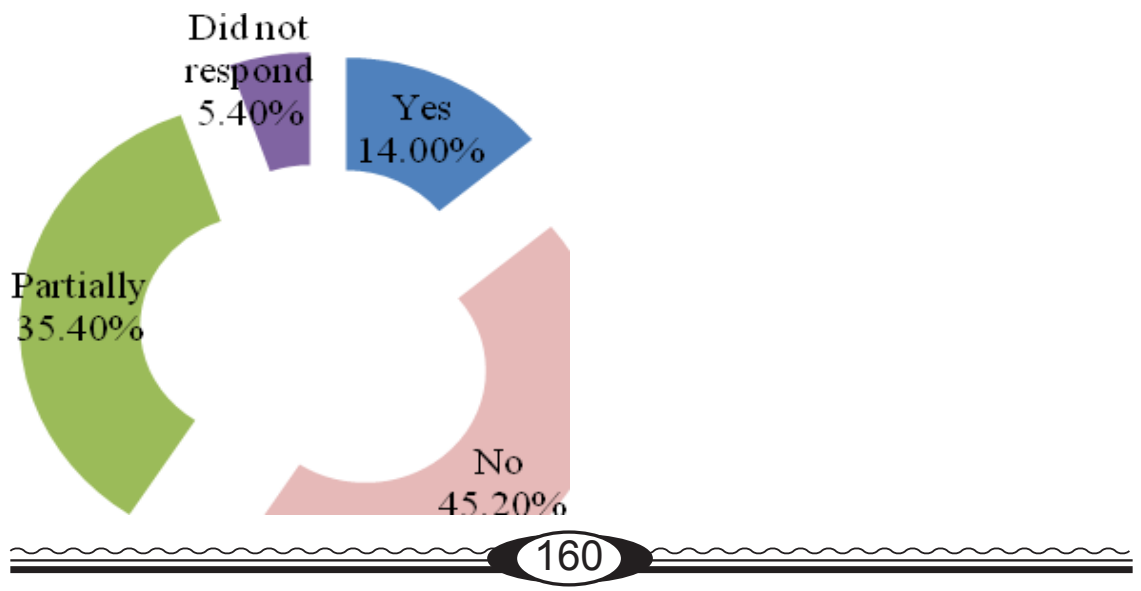


Q. 4. Does a present syllabuses/text book address the issues like terrorism, religious and ethnic intolerance?

Only 14\% respondents shared "Yes" that present syllabuses and text books address some issues on terrorism, religion and ethnicity. Majority $45.20 \%$ responses "No" and therefore a probing question was to know their opinions on necessity to include these issues in education.

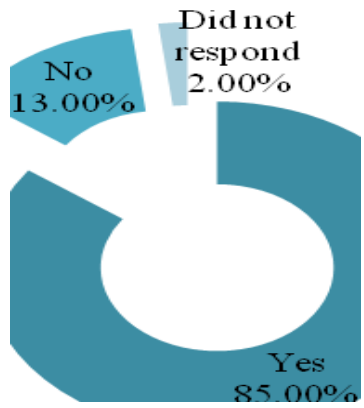

Q. 5. Do you think it is necessary to include the issues like counter terrorism, religious and ethnic intolerance into the syllabuses/text books? $85 \%$ respondents said "Yes" and they think it are necessary to include issues into the syllabuses/text books to face the challenges of terrorism, religious and ethnic intolerance. 13\% respondents said "No" and 2\% respondents did not respond to the question.

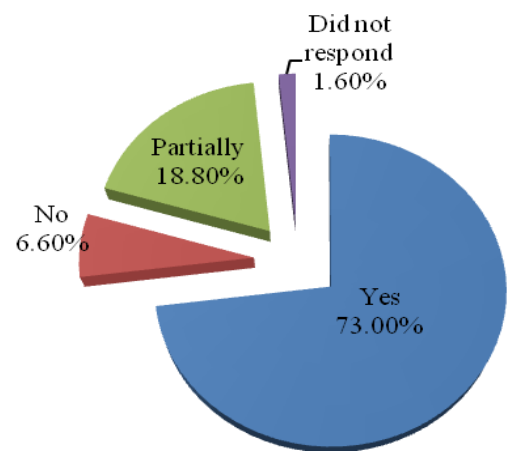

Q.6. Do you think inclusion of the issues like terrorism, religious and ethnic intolerance into the syllabuses/text books will give any benefit to face these challenges?

It was also asked about the benefit regarding inclusion of these issues in textbooks/syllabuses, 73\% respondents said 'Yes' about this. 


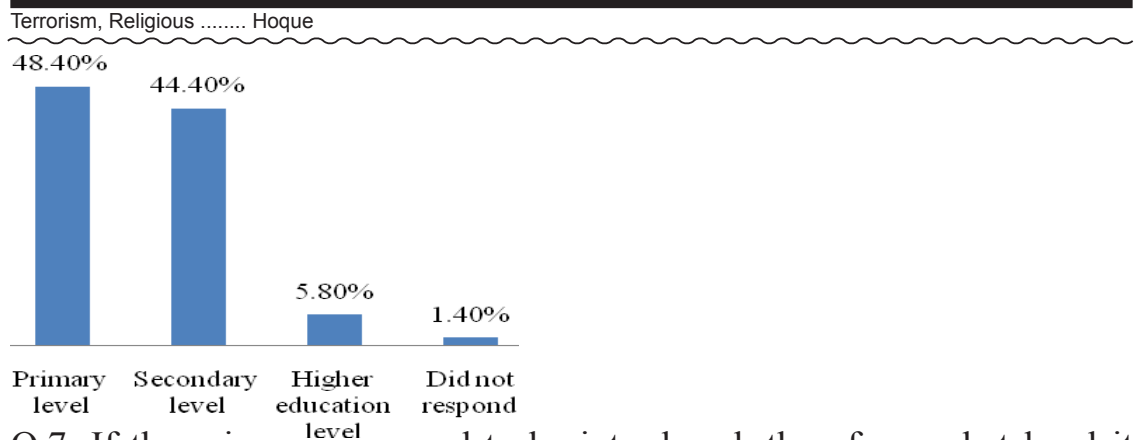

Q.7. If these issues arele, need to be introduced, then from what level it should be?

Respondents were provided a list on from what level it could be included. $48.40 \%$ people responded that it should be included from primary level. $44.40 \%$ respondents said that secondary level is appropriate for inclusion. Over all it could be said that combining all school age is the appropriate level to deliver the issues through education.

\subsection{Ideas on including the concept of counter terrorism, religious, and ethnic intolerance in syllabuses/text books:}

To know activities that could be done to include the aforementioned issues in textbooks and syllabuses; an open ended question was asked. Respondents answered very openly on the issue, where as many refused to comment. According to one respondent, initiative could be like;

"Recent incidents need to incorporate in contents for students according to their education level. Some issues related to human rights can be given as story."

Respondents shared their ideas on what should be done to include these issues in education as well as in syllabuses and textbooks. Different ideas have been shared including, introducing new chapters and contents in syllabuses and textbooks; introduce moral education as a new subject was most common. Few respondents also emphasized on religious theme based education. Advocacy and Government initiatives have also been suggested. A major portion also shared about teacher's involvement and initiative to address these issues. Teacher's manual is needed to have some instructions on dealing and addressing these issues. Respondents also shared about the source, causes and effects of terrorism and terrorist acts. Global perspective of issues on terrorism, religious and ethnic intolerance was also suggested.

One respondent wrote; "national and international incidents associated to terrorism and religious intolerance and its consequences need to 
incorporate in textbook to aware students"

When children will be aware that, terrorism, religious and ethnic intolerance is not just national issues but globally these treat as emergence issues, then they will be able to understand the depth of the problem. So, these issues should be treated in global perspectives in link to all culture and society.

\section{Conclusion}

The most significant findings of the study is there is almost nothing in the syllabuses and text books of general and madrasha education streams to create awareness among the students for countering terrorism, religious and ethnic intolerance in Bangladesh.

Moreover, it is revealed during this study that most of the Bangladeshi people $(71.6 \%)$ think terrorism, religious and ethnic intolerance is a problem for Bangladesh. 52.60\% people are concern about the issues of, terrorism, religious and ethnic intolerance, and 37\% think about the issues partially.

It has been observed during data collection that, $75 \%$ student shared that they do not have any chapter or topic related to counter terrorism, religious and ethnic intolerance in syllabuses or text books. Only 14\% respondents shared "Yes" that present syllabuses and text books address some issues on terrorism, religion and ethnicity.

$85 \%$ respondents think it's necessary to include these issues into the syllabuses/text books to face the challenges of terrorism, religious and ethnic intolerance. It was also asked to the people about the benefit regarding inclusion of these issues in textbooks/syllabuses, 73\% respondents said 'Yes' about this. 48.40\% people responded that the issues should be included from primary level. $44.40 \%$ respondents said that secondary level is appropriate for inclusion. Over all it could be said that combining all school age is the appropriate level to deliver the issues through education.

Respondents shared their ideas on what should be done to include these issues in education as well as in syllabuses and textbooks. Different ideas have been shared including, introducing new chapters and contents in textbooks; introduce moral education as a new subject was most common. Few respondents also emphasized on religious theme based education. Advocacy and Government initiatives have also been suggested. A major 
portion also shared about teacher's involvement and initiative to address these issues. Teacher's manual is needed to have some instructions on dealing and addressing these issues. Respondents also shared about the source, causes and effects of terrorism and terrorist acts. Global perspective of issues on terrorism, religious and ethnic intolerance was also suggested. Time has come to promote the knowledge regarding mutual understanding and respect for diversity, along with countering all forms of intolerance and discrimination for educating the people from their early learning stages. It is urgently needed to reassess the national education policy and formulate curriculum/syllabuses/text books with such ideas which will eliminate the orthodox religious ideas and will aware teachers and students as well as everyone regarding the issues of terrorism, religious and ethnic intolerance from the elementary level.

\section{Endnotes:}

${ }^{1}$ The most prominent ones are as follows: Al-Harat Al-Islamia, Allar Dal Brigade, Al-Markajul Al-Islami, Al-Jihad Bangladesh, Ahle-Hadis, Al-Kurat, Al-Islami Martyars Brigade, Al-Khidmat, Amirate-Din. Al-Sayeed Mujaheed Bahini, AlTanjeeb, Arakan Mujaheed Party (and other groups carrying 'Arakan' names), Harkat-ul Jihad, Harkat-ul-Islam Al-Jihad, Hijbut Tawheed,Hijbut Tahrir, Islami Bipplobi Parishad, Iktadul-Talah Al-Muslemin, Jama'aetul Mujahideen Bangladesh (JMB), Jaggrata Muslim Janata, Joyshe Mohammad, Joyishe Mostafa, Jangi Hakikat, Jamaeet-ul Falayia, Jamaat-e-Yahiya Jummatul AlSadaat, Sahadat-e-Al-Hikma, Shahadat-e-Nobuyot, Hizabullah Islami Samaj, Hizbul Mahadi, Ibtedatul Al-Muslemia, Jamiayeete Islami Solidarity Front, Rohingya Independence Force (and other groups carrying 'Rohingya' name), Tahfize Harmayin, Khedmate Islam, Islahul Muslemin, Islami Liberation Tiger, Ta-Amir Ud-Din, Tauheedi Janata.

${ }^{2}$ According to Human Rights Report 2011 on Indigenous Peoples in Bangladesh, in 2011, 7 indigenous people, from CHT and 4 from plain lands were killed while 13 persons were arrested or detained. In addition, 30 indigenous persons, 29 victims are from CHT out of them, were tortured, harassed, and threatened. At least 8 massive communal attacks were made upon Indigenous Peoples across the country. Of them, 4 attacks were made in the CHT. Bengali settlers committed all the communal attacks in the CHT and in these attacks; and the role of security forces in to some extents is questionable. At least 3 indigenous persons were killed in these communal attacks while 70 were injured. Besides, 137 houses of Indigenous Peoples were completely burnt to ashes while 47 houses were looted or 
ransacked. Religious persecution on Indigenous Peoples also continued, particularly in the CHT.

\section{References}

Barakat, A. (2011a). Economics of fundamentalism and the growth of political Islam in Bangladesh. Dhaka.

Barakat, A. (2011b). Economics of fundamentalism and the growth of political Islam in Bangladesh. Retrieved 2012 from http://www.secularvoiceofbangladesh.org/article $\% 20$ by $\% 20$ Abul\%20Barkat.htm

Barman, D. C. and Neo, M. S. (Eds.). (2012). Human Rights Report 2011 on Indigenous Peoples in Bangladesh, 126. Dhaka: Kapaeeng Foundation.

Election Commission of Bangladesh (2012). Registered politcal parties in Bangladesh. Retrieved from http://www.ecs. gov.bd/Bangla/PrintMenuHeader.php?MenuID=53

Hindu American Foundation (2011). Human rights in Bangladesh: Excerpts From Hindus in South Asia and the Diaspora, 2011. Retrieved from http://www.hafsite.org/humanrights-issues/human-rights-bangladesh-excerpts-hindussouth-asia-and-diaspora-2011

PCJSS (2012). Human rights violations (1998-2009). Retrieved from http://pcjss cht.org/At\%20A\%20Glance\%20\%2819982010\%29.php

South Asia Terrorism Portal-SATP (2012). Fatalities - Left-wing extremism 2005-2012. Retrieved from http://www.satp.org/ satporgtp/countries/bangladesh/database/Fatalities-\%20 Left-wing\%20Extremism\%202010.htm 